\title{
Postharvest Technology of Imported and Trans-shipped Tropical Floricultural Commodities
}

\author{
Rik van Gorsel \\ Research Station for Floriculture, Linnaeuslaan 2a, 1431 JV Aalsmeer, The Netherlands
}

World trade in floricultural products is expanding, due in large part to diminished technological and political barriers, improvements in infrastructure, and the recognition by many developing countries that floricultural products can be an important source of foreign currency. Along with this increase in international trade comes the demand for improved quality and quality control. However, what constitutes quality of these highly perishable commodities is poorly defined. External appearance is a poor measure of eventual quality at the consumer level. Thus, predictive tests and quantitative measures of internal quality are needed.

\section{WORLD TRADE IN FLORICULTURAL PRODUCTS}

The total intercontinental trade in floricultural products exceeds 1.250 million U.S. dollars (Heinrichs and Siegmund, 1992). Cut flowers account for most of it (Table 1). The remainder consists of foliage greens, bulbs, nursery stock, and live plants. Flowers are a luxury product. There are only three major world markets: North America, Japan, and Europe. Because of the predominantly temperate and Mediterranean climates in these markets, they depend largely on imports from the tropics and the southern hemisphere for their supply of exotic and out-of-season products. Still, intercontinental trade of floricultural products is small compared to a total consumption of 25 billion U.S. dollars in these markets. Overseas suppliers to these countries are mostly on the nearest continent. Colombia is the main foreign supplier of the North American market, with an import value of $>200$ million U.S. dollars (Table 1). The contribution of other Central and South American countries and Mexico is much less. A similar situation exists in Japan, which also imports most cut flowers from its southern neighbors. In volume, imports from Thailand into Japan are larger than those from Europe (Gunneröd, 1991). Increased air traffic between Japan and Australia and New Zealand has given these southern hemisphere countries an opportunity to increase their flower exports.

Nevertheless, significant imports come from even more distant production areas. The Netherlands has been a large supplier of seasonal products, such as tulips, to the American market. The share of these cross-Atlantic imports has declined recently because of the diversification of the Colombian flower industry and the continued increase in local production (Hack and Heybroek, 1992). The Netherlands supplies specialty products to Japan as well. The import of Colombian products on the Japanese market is small, but is growing steadily. The import of Colombian products into Europe has shown the largest increase and is expected to continue to increase.

Europe accounts for almost $50 \%$ of world imports of cut flowers. More than half of the flowers imported into Holland come from overseas (Table 2). Germany imports only a small portion of its cut flowers from overseas, but because of its enormous total consumption, it is still the second major importer. As distance from the Dutch distribution system increases, the volume of direct overseas imports increases. Israel is the major exporter of cut flowers to Europe. The United States is an important supplier of foliage greens (Produktschap voor Siergewassen, 1992). Tropical countries that are major exporters to Europe include Colombia, Costa Rica, Kenya, the Canary Islands, and Thailand. Many of the imports from these tropical countries are actually temperate or Mediterranean-type products. Roses and carnations are by far the largest volume products and are imported in the winter months (Hack and Tap, 1990).

The amount of exotic products imported into Europe is comparatively small: <200 million U.S. dollars. The actual value depends on what one considers to be an exotic product-a distinction made difficult by seasonal and protected cultivation. Because of the difficulty of getting European data, the imports discussed later are limited to imports into the Netherlands, which serves as a gateway for most of the specialty products imported into Europe. Exotic products are a very diverse group; most are cut flowers used in the more expensive mixed bouquets, and diversity, therefore, is important. Some of the more important ones are Limonium latifolium (Sm.) Kuntze, Chamelaucium uncinatum Schauer, Solidaster, Liatris, orchids, and Protea. Only about $5 \%$ to $30 \%$ of these crops is grown in Dutch greenhouses (Association of Dutch Flower Auctions, 1993). Limonium latifolium accounts for an auction value of 25 million U.S. dollars. Liatris is much less important, with a value of $\approx 7$ million U.S. dollars. Proteas are less important on the European market. Most of the imported orchids come from Thailand, but imported orchids account for only a small part of the total.

The imports of flowers native to the tropics, such as Alpinia purpurata (Vieill.) Schum. (red ginger), Heliconia spp., Gomphrena globosa L., Stephanotis floribunda (R. Br.) Brongn., and Strelitzia reginae Banks esc. Dryand., are small. Amaranthus spp., Anthurium andraeanum Linden, Celosia argentea L., Zantedeschia aethiopica (L.) Spreng., and many other tropical flowers are actually grown more in greenhouses than imported. Even though cut flowers have the lowest transport cost per unit, they are not the only exotic commodities imported into the European market. Singapore supplies potted orchids and plants. Costa Rica is a large supplier of tropical foliage and unrooted cuttings, such as yucca (Yucca elephantipes Regel) stems.

\section{DETERMINANTS OF INTERNATIONAL TRADE}

The perishability of floricultural commodities puts high demands on all aspects of intercontinental trade. Some of the more important determinants are market structure and organization, government regulations, infrastructure, and information exchange.

Good market structure and organization are essential. Too many links (brokers, shippers, receivers, retailers, etc.) lengthen the time in the marketing chain, because often each link sells the products from stock. Even with a system of central auctions, a product will have

Table 1. Overseas trade of cut flowers in 1990 and 1991 based on import values. $^{2}$

\begin{tabular}{|c|c|c|c|c|c|c|}
\hline \multirow[b]{3}{*}{ Origin } & \multicolumn{6}{|c|}{ Destination } \\
\hline & \multicolumn{2}{|c|}{$\begin{array}{c}\text { USA and } \\
\text { Canada }\end{array}$} & \multicolumn{2}{|c|}{ Japan } & \multicolumn{2}{|c|}{$\begin{array}{l}\text { Western } \\
\text { Europe }\end{array}$} \\
\hline & 1990 & 1991 & 1990 & 1991 & 1990 & 1991 \\
\hline & \multicolumn{6}{|c|}{ millions of U.S. dollars } \\
\hline Colombia & 192 & 202 & 3 & 6 & 73 & 113 \\
\hline Rest of America & 34 & 42 & 4 & 5 & 17 & 24 \\
\hline Thailand & 3 & 5 & 25 & 29 & 27 & 32 \\
\hline Rest of Asia & 2 & 3 & 37 & $53^{y}$ & 6 & 8 \\
\hline Israel & --- & $--^{x}$ & --- & --- & 121 & 130 \\
\hline $\begin{array}{l}\text { Rest of West Asia } \\
\text { and Northwest Africa }\end{array}$ & --- & --- & --- & --- & 41 & 44 \\
\hline Kenya & --- & --- & --- & --- & 38 & 47 \\
\hline Rest of sub- & & & & & & \\
\hline Saharan Africa & --- & --- & --- & --- & 30 & 35 \\
\hline Netherlands & 65 & 51 & 44 & 52 & na & $\mathrm{na}^{\mathrm{w}}$ \\
\hline Rest of Europe & 5 & 4 & 1 & 1 & na & na \\
\hline Total overseas & & & & & & \\
\hline imports & 302 & 307 & 115 & 146 & 356 & $434^{v}$ \\
\hline 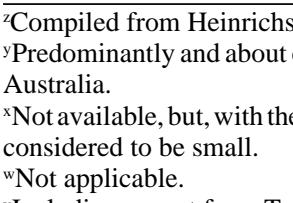 & $\begin{array}{l}\text { id Sieg } \\
\text { ually fr }\end{array}$ & $\begin{array}{l}\text { und ( } \\
\text { m Tai }\end{array}$ & $\begin{array}{l}91,199 \\
\text { in, New }\end{array}$ & Cealan & Singap & $\begin{array}{l}\text { e, and } \\
\text { States, }\end{array}$ \\
\hline
\end{tabular}


Table 2. Value of floricultural products imported into western European countries in 1990 and 1991.

\begin{tabular}{|c|c|c|c|c|c|c|c|c|}
\hline \multirow[b]{3}{*}{$\begin{array}{l}\text { Importing } \\
\text { country }\end{array}$} & \multicolumn{4}{|c|}{ Imports (millions U.S. dollars) } & \multirow{2}{*}{\multicolumn{2}{|c|}{$\begin{array}{l}\text { Percent total } \\
\text { from overseas }\end{array}$}} & \multirow{2}{*}{\multicolumn{2}{|c|}{$\begin{array}{c}\text { Share (\%) of } \\
\text { overseas imports }\end{array}$}} \\
\hline & \multicolumn{2}{|c|}{ Total } & \multicolumn{2}{|c|}{ From overseas } & & & & \\
\hline & 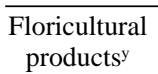 & $\begin{array}{c}\text { Cut } \\
\text { flowers }\end{array}$ & $\begin{array}{l}\text { Floricultural } \\
\text { products }\end{array}$ & $\begin{array}{c}\text { Cut } \\
\text { flowers }\end{array}$ & $\begin{array}{l}\begin{array}{l}\text { Floricultural } \\
\text { products }\end{array}\end{array}$ & $\begin{array}{c}\text { Cut } \\
\text { flowers }\end{array}$ & $\begin{array}{l}\text { Floricultural } \\
\text { products }\end{array}$ & $\begin{array}{c}\text { Cut } \\
\text { flowers }\end{array}$ \\
\hline Netherlands & 436 & 169 & 244 & 122 & 56 & 72 & 33 & 29 \\
\hline Germany & 2150 & 1144 & 183 & 89 & 9 & 8 & 25 & 21 \\
\hline Great Britain & 549 & 268 & 84 & 70 & 15 & 26 & 11 & 17 \\
\hline Italy & 438 & 113 & 47 & 28 & 11 & 25 & 6 & 7 \\
\hline Switzerland & 296 & 130 & 35 & 24 & 12 & 19 & 5 & 6 \\
\hline Austria & 178 & 76 & 25 & 16 & 14 & 21 & 3 & 4 \\
\hline France & 746 & 301 & 30 & 18 & 4 & 6 & 4 & 4 \\
\hline Other countries & 866 & 260 & 87 & 71 & 10 & 27 & 12 & 17 \\
\hline Total (1991) & 5659 & 2460 & 734 & 421 & 13 & 17 & 100 & 100 \\
\hline Total (1990) & 5003 & 2115 & 615 & 343 & 12 & 16 & & \\
\hline Increase, 1990-91 (\%) & 13 & 16 & 19 & 23 & & & & \\
\hline
\end{tabular}

${ }^{2}$ Western Europe $=$ countries of the European Community and European Free Trade Association.

${ }^{y}$ Cut flowers, bulbs, foliage green, potted plants, and nursery stock. Compiled from Heinrichs and Siegmund (1991, 1992).

changed hands four times before it gets to the consumer. At least one more link is added to the chain if the product is first imported. Delivery of unsold products to the destination market can decrease the marketing time. For example, flowers from Israel are shipped unsold to Dutch auctions, and Colombian flowers are often delivered unsold to Miami. In contrast, products from the Netherlands are only shipped to overseas markets after sale.

Government regulations, such as phytosanitary requirements and tariffs, can greatly affect international trade. Tariffs on Colombian products imported into the European community were lifted after the Colombian authorities agreed to enforce the payment of royalties to, mostly Dutch, plant breeders. Phytosanitary requirements affect the range of products that can be imported and the time it takes those products to pass customs. Japan has strict phytosanitary requirements. As a consequence, $30 \%$ of flowers imported into Japan do not pass inspection and have to be fumigated (Gunneröd, 1991). Viruses and soilborne pathogens are feared most: overseas import of cut flowers into the United States and Canada is much larger than the import of live plants (307 vs. 26 million U.S. dollars; Heinrichs and Siegmund, 1991). In contrast, trade in live plants between the United States and Canada exceeds 100 million U.S. dollars. To alleviate losses incurred due to phytosanitary requirements, agricultural inspectors from the import country could inspect and certify the products in the country of origin. This is done for export from the Netherlands to Japan.

The infrastructure and mode of transport is another important determinant of international trade, because it directly affects quality. In terms of speed, transport by airplane seems to be the most logical choice for intercontinental trade. However, temperature control is often poor, both in the airports and on the planes. Transport on either end of the intercontinental leg must connect well. Transport by boat is not yet an option, but it could become an alternative for production and destination areas that are close to the sea and have good port facilities, e.g., trans-Atlantic and inter-Asian trade. The shipping industry has gained experience in containerized, modified-atmosphere transport with other horticultural commodities. Currently, ships sail on time schedules almost as strict as airplanes.

Intracontinental trade is mostly by truck because of its low cost and because the product reaches its final destination without trans-shipment and with minimal handling. Transport by truck has good possibilities for temperature control, but that advantage is not always used fully.

Information exchange has long been neglected. Two-way communication can be lacking, especially with the delivery of unsold products to the destination market. Not being aware of the eventual quality or of the changes in consumer demand can seriously impede long-term export possibilities.

\section{POSTHARVEST HANDLING}

\section{Product requirements}

Postharvest requirements involve both the criteria that products have to meet and the conditions and treatment that a product demands.
The criteria for floricultural products to withstand postharvest handling successfully are similar for imported and locally grown commodities. Some of the more important criteria follow.

Cut flowers and potted plants should have enough carbohydrate reserves to develop fully. A low sensitivity to and production of ethylene will reduce the effect of many transport-related problems. The right maturity stage at harvest is essential. Immature flowers can lack not only the carbohydrate reserves to come to full bloom, but also the hormonal signaling that guides their development. However, products of higher maturity can be more sensitive to transport damage and ethylene.

The ability to withstand transport is another important criterion. It includes resistance to moderate water stress, darkness (live plants and foliage green), and fungal and bacterial pathogens. For imported commodities, the ability to withstand quarantine treatment can be an additional criterion.

The main difference between imported and nonimported products is the time spent in the marketing chain. Importing requires a much stricter adherence to product demands.

The most important measure that can be taken to meet these demands is temperature control. Low temperatures slow the development and depletion of carbohydrate reserves. They also decrease ethylene production and sensitivity and limit pathogen growth. The chilling sensitivity of tropical products defines the lower limit of the acceptable temperature range.

The second most important measure is cleanliness. Cut flowers demand strict hygiene, starting immediately after harvest with clean containers that contain a suitable bactericide solution. Adverse conditions at any time can allow bacteria to occlude the stem or fungi to infect the bloom.

Adequate water should be available to flowers to avoid prolonged water stress. Therefore, flowers should be turgid before they are shipped and be allowed to rehydrate after unpacking. However, excessively high turgor increases the chance of damage during packing. A small vapor pressure deficit during transport will reduce water loss from the product; this requires a well-designed vapor barrier and good temperature control, because condensation will increase the chance of spoilage.

Rooted plants can have a high susceptibility to water stress as well. An additional requirement for live plants is the need for light immediately after shipment to recover from dark transport.

Packaging can be a major aid in controlling temperature and relative humidity. However, packaging often seems to be designed to prevent mechanical, not physiological, damage.

For a well-chosen variety grown under good conditions, the above measures should suffice. In practice, product and handling conditions are seldom optimal and additional measures, mostly in the form of chemicals applied to the cut flower before packing, are often taken. Therefore, apart from a bactericide, pretreatment solutions often contain one or more of the following: sugar, an anti-ethylene agent (silver thiosulfate or amino-oxyacetic acid), a surfactant to aid in rehydration, and gibberellin to reduce leaf yellowing. 


\section{Marketing chain evaluation}

A complete marketing chain evaluation was conducted in 1987 and 1988 to determine to what extent good handling practices were implemented and what improvements should be made (Bloemen Marketingbureau Holland, 1988). This extensive study dealt mostly with temperate-climate (Dutch) products. Time, water availability, packaging, and organization affect quality most. The conclusions could be summarized in two general statements: "Potential vase life is reduced by 5 to $10 \%$ for each day spent in the marketing chain" and "Postharvest requirements for individual products are seldom met." Simulated transport conditions confirmed this. Rehydration of packed Bouvardia was blocked by $20 \mathrm{~h}$ of water stress at 17C (van Meeteren, 1990). This quality loss is obvious, but it also can be hidden and noticeable only when the product is with the consumer. The vase life of packed spray carnations (Dianthus caryophyllus L.) kept for $40 \mathrm{~h}$ at 20C is reduced by up to 4 days compared to the same flowers kept at 8C (M.B.M. Ravesloot and R. van Gorsel, unpublished data). Forty hours of dryness at $20 \mathrm{C}$ represents the intercontinental link in the marketing chain. Another example is Aster ericoides L. 'Monte Casino': $40 \mathrm{~h}$ at $20 \mathrm{C}$ will reduce the vase life by 3 to 6 days compared to stems kept at $8 \mathrm{C}$. Two types of flowers of similar visual maturity can reach the customer: either flowers harvested when immature and marketed with inadequate temperature control or flowers harvested when more mature and kept at a constant, lower temperature. Because of insufficient temperature control, the trade often chooses and pays the grower more for the inferior, immature products.

\section{External and internal quality}

Many definitions of quality exist. A practical definition is: Quality is the extent to which a product meets the requirements of the customer. The customer being each successive link in the marketing chain, the last link being the consumer. Quality, therefore, means something different to the producer, exporter, retailer, and consumer. The carnation and aster examples show that these requirements can be in conflict. Exporters prefer immature carnations (early bud stage) because these flowers withstand tight packing during shipping better and allow more leeway in time and temperature. The same is true for roses (Rosa hybrida L.). Slow-opening roses of low maturity are preferred to the point that many flowers will not open at all.

Therefore, one should look for internal rather than external quality. Two important characteristics of internal quality are that it is invisible at the time of transaction and essential to consumer satisfaction. Because of these characteristics and because repercussions only come much later and do not harm the violator more than the trade as a whole, it is necessary to be able to measure internal quality. Internal quality tests should be effective for both freshly harvested commodities and products at later stages in the marketing chain. Another requirement is that internal quality can be established at the moment of sale.

\section{Tests to measure internal quality}

Developing tests to measure internal quality is an important area of research at the Research Station for Floriculture at Aalsmeer. Obviously, there is no one single test to measure internal quality. Some examples of current research are given below. Near infrared reflectance (NIR) and transmittance spectroscopy have been evaluated for predicting the vase life of Freesia at the time of auction. Thus far, the precision in predicting vase life is not accurate enough to warrant commercial application (van der Pluym et al., 1993). Starch content of the first-coloring flower bud of lily (Lilium, Asiatic hybrids group) can be used in predicting vase life, provided that it has been treated with silver thiosulfate (G. Slootweg, unpublished data). Bacterial counts in rose stems correlate with their sensitivity to bent neck during summer (G. Slootweg, unpublished data). Spot checks of bacterial counts inside flower stems are used to enforce bactericide pretreatment. A check, by means of enzyme-linked immunosorbent assay, on pretreating Alstroemeria with gibberellin was developed elsewhere (Franssen et al., 1992). Developing and implementing these and comparable tests should eventually make it possible to introduce a quality certificate.

\section{EXTENSION NEEDS AND RESEARCH DIRECTIONS}

International trade in floricultural products is a growing business. It will only stay a flourishing business if there is a consensus about the need for good quality. Extension efforts should be extended to all parts of the production and marketing chain. They should emphasize temperature control, hygiene, and product knowledge. This goal could be achieved, for example, through short courses where representatives of all links in the marketing chain participate. The conditions are right to show that trading in high-quality products has financial benefits. Extension efforts should also include the promotion of internal quality tests. This implies that extension needs to be supported by research in this area. Research on underlying physiological processes, such as those involved in flower opening, water relations, the influence of growing conditions on postharvest quality, further improvements in postharvest technology, and genotype improvement also are necessary.

These research and extension efforts should remove barriers to international trade. International collaboration is the key to solving these problems.

\section{Literature Cited}

Association of Dutch Flower Auctions. 1993. Statistiekboek 1992. Assn. Dutch Flower Auctions, Leiden, The Netherlands.

Bloemen Marketingbureau Holland. 1988. Ketenonderzoek Bloemisterijprodukten; Eindrapport. Bloemen Marketingbureau Holland, The Hague, The Netherlands.

Franssen, J.M., C.H. Kersten, and K.M. Lameris. 1992. Toets maakt voorbehandeling Alstroemeria controleerbaar. Vakblad voor de Bloemisterij 47(28):28-29.

Gunneröd, P. 1991. Marketing cut flowers in Japan and Hong Kong. Intl. Trade Forum 27(3):28-29.

Hack, M. and A.M.A. Heybroek. 1992. Visie op de internationale concurrentiekracht in de bloemisterij. Rabobank, Eindhoven, The Netherlands.

Hack, M.D. and H. Tap. 1990. Floricultural products; A survey of the Netherlands and other major markets in the European community. CBI, Rotterdam, Netherlands.

Heinrichs, F. and I. Siegmund. 1991. Yearbook of the international horticultural statistics; Non-edible horticultural products. vol. 39. Intl. Verband des Erwebsgartenbaues, The Hague, The Netherlands.

Heinrichs, F. and I. Siegmund. 1992. Yearbook of the international horticultural statistics; Non-edible horticultural products. vol. 40. Intl. Verband des Erwebsgartenbaues, The Hague, The Netherlands.

Produktschap voor Siergewassen. 1992. Jaarverslag 1991. Produktschap voor Siergewassen, The Hague, The Netherlands.

van der Pluym, I., N. Marissen, and R. Frankenhuizen. 1993. Nauwkeurige bloeivoorspelling Freesia nog niet mogelijk. Vakblad voor de Bloemisterij 47(6):29.

van Meeteren, U. 1990. Slappe bladeren Bouvardia veroorzaakt door lucht in stengels. Vakblad voor de Bloemisterij 45(7):39. 